\title{
THREE NEW AFRICAN SPECIES OF MORDELLID BEETLES
}

\author{
By Eugene Ray \\ Chicago, Illinois
}

The following descriptions were made from a lot of eleven specimens collected in the Sudan region of Africa by A. P. G. Michelmore and R. C. M. Darling and sent to the writer by Sir Guy A. K. Marshall, Director of the Imperial Institute of Entomology, British Museum (Natural History). The types of the new species hereinafter described are temporarily placed in the Chicago Natural History Museum, while paratypes remain in the collection of the writer.

\section{Tomoxia abrupta new species}

Form short, sides subparallel, derm generally black, with the following exceptions: anterior and intermediate legs and seven distal segments of antennæ fuscocastaneous; four proximal segments of antennæ, palpi, front, and mesal margin of mandibles castaneous. Body densely covered with fine recumbent pubescence, a solid golden on head and pronotum, black on scutellum, an irregular golden area covering basal third of elytra, enclosing an irregular black area on either side of scutellum near base, an irregular, transverse, golden band behind middle, reaching suture but not middle and connected with basal area by a short sutural line, with intervening and subsequent areas blackishpubescent; ventral surface blackish-pubescent, except for the following whitish areas: meso- and metasternum, 1st and 2nd abdominal segments (except at apical margin), and third segment along basal margin.

( $q$ ). Antennæ $1.4 \mathrm{~mm}$. long, reaching metasternum; segments 1 and 2 equal; 3 distinctly longer than 4, latter broadest at apex; 5 as long as 3 , but broader; $6-10$ strongly serrate, as broad as long; 11 one-half longer than 10, inner margin and apex rounded, broadest at middle. Terminal segment of maxillary palpi enlarged, with form of a scalene triangle, sides and angles all strongly rounded, mesal margin thickest, divided longitudinally, 
with a concave, elongate depression between the edges. Head strongly flattened antero-posteriorly, front, clypeus, and vertex forming a straight line. Eyes reaching occiput.

Pronotum distinctly broader than long $(2.0 \times 1.8 \mathrm{~mm}$.), anterior margin and sides rounded, base arcuate, midbasal lobe short, broad, subtruncate. Scutellum subquadrate, sides but slightly angular, apical margin truncate.

Elytra short, but four-tenths longer than broad $(3.2 \times 2.0$ $\mathrm{mm}$.), sides attenuate to apex, apices individually rounded. Anal style short, thick, truncate at apex, but one-half longer than hypopygium $(1.5 \times 1.0 \mathrm{~mm}$. $)$. Posterior tarsal claws with five teeth, two premedian, the first very small, the other distinct; three postmedian, first larger than any other except terminal one, second small, third terminal.

$\left(\sigma^{\top}\right)$. The males are darker, the castaneous parts of the female being almost piceous in this sex. The elytral markings are more restricted, the posterior band being curved anteriorly at the suture and lateral margins.

Length: to apices of elytra, $3.3-5 \mathrm{~mm}$.; to tip of anal style, 4.3-6.5 $\mathrm{mm}$.

Five specimens: male type and two male paratypes, Wady Madu, N. E. Darfur, July 25, 1930, at flowers of Premna resinosa (Michelmore); one male paratype, Plain below J. Kaboija, J. Midob, N. E. Darfur, August 7, 1930, common on leaves and flowers of large succulent grasses (Michelmore); one female paratype, Duani, wilderness of Toganoy, N. E. Darfur, August 12, 1930, on foliage of Grewia flavescens (Michelmore).

This species may easily be separated from the only other African member of the genus, T. robusta Pic (Rev. zool. bot. afr. 21, 1931 , p. 45), by the wholly different pubescent markings, the unicolored abdomen and legs, the bicolored antennæ, and the larger size. Mr. Pic's short diagnosis unfortunately does not permit a more adequate comparison.

\section{Mordellistena sudaniensis new species}

Form elongate, sides subparallel, derm generally black, with the following exceptions: anterior and intermediate legs, front, palpi, and three basal antennal segments flavocastaneous; posterior legs fuscocastaneous. Body densely covered with fine, recumbent, cinereous pubescence and minute, closely-placed tubercles. 
Antennæ $0.9 \mathrm{~mm}$. long, reaching metasternum; segments 3-4 equal in length, the latter a little broader; 5-10 each one-third longer than 4 and almost twice as broad as 3, broadest subapically; 11 one-half longer than 10 , sides and apex rounded, broadest medially. Terminal segment of maxillary palpi enlarged, slender, three times as long as broad at widest point, ovoid, outer side somewhat less rounded than inner margin, broadest on apical half.

Pronotum as long as broad $(0.8 \mathrm{~mm}$.), sides and apex rounded, base arcuate, midbasal lobe short, subtruncate.

Elytra two and three-fourths times as long as broad $(2.2 \times 0.8$ $\mathrm{mm}$.), sides subparallel to within a fourth of apex, then strongly curved, apices individually rounded. Anterior and intermediate tarsi longer than their tibiæ. Posterior tibiæ with two strong ridges (excluding subapical one), the anterior extending obliquely entirely across outer face; basitarsi with three, second segment with two oblique ridges. Anal style short, subtruncate at apex, but twice length of hypopygium $(0.7 \times 0.35 \mathrm{~mm}$.).

Length: to apices of elytra, $3 \mathrm{~mm}$.; to tip of anal style, $3.7 \mathrm{~mm}$.

Four specimens. Type, male, and two female paratypes, El Wuz, September 17, 1931, at light (Darling); a male paratype, Plain below J. Kaboija, J. Midob, N. E. Darfur, August 7, 1930, common on leaves of large succulent grasses (Michelmore).

This species is allied to diffinis Mäklin (Acta Soc. Sci. Fenn. 10, 1875 , p. 586 ), but may easily be separated by the larger size, the much shorter anal style, the lighter appendages, the shorter and broader pronotum and elytra, and the elongate anterior ridge of the posterior tibiæ.

\section{Mordellistena darfurensis new species}

Form elongate, sides subparallel; head, mouth parts, antennæ (outer segments darker), pronotum, and anterior and intermediate legs, flavo- or fuscocastaneous, thorax sometimes with an indefinite dorsal cloud; meso- and metasternum, abdomen, posterior legs, and elytra, black. Body densely covered with fine, recumbent, flavocinereous pubescence.

Antennæ $1 \mathrm{~mm}$. long, reaching metasternum; segments 3-4 equal; 5-10 each one-third longer than 4 and considerably broader, broadest subapically; 11 one-third longer than 4 and considerably broader; 11 one-third longer than 10 , sides and apex rounded, broadest medially. Terminal segment of maxil- 
lary palpi enlarged, slender, two and one-half times as long as broad, with the form of a scalene triangle, outer edge straight, other margins and angles rounded, broadest at a postmedian point.

Pronotum as long as broad (1 mm.), sides and angles broadly rounded, basal angles obtuse, base arcuate, midbasal lobe short, subtruncate.

Elytra two and seven-tenths times as long as broad $(2.7 \times 1$ $\mathrm{mm}$.), sides subparallel on basal half, thence distinctly curved to apex, apices individually rounded. Anterior and intermediate tarsi longer than their tibiæ. Posterior tibiæ with three strong, equal ridges (excluding subapical one); basitarsi with three (one specimen with a rudimentary fourth), second segment with two oblique ridges. Anal style moderately long, attenuate, subtruncate at apex, two and one-third times length of apical ventral segment $(1.4 \times 0.6 \mathrm{~mm}$. $)$.

Length: to apices of elytra, $3.7 \mathrm{~mm}$.; to tip of anal style, $5.1 \mathrm{~mm}$.

Two specimens: Type from Plain below J. Kaboija, J. Midob, N. E. Darfur, August 7, 1930, on leaves and flowers of large succulent grasses; paratype from N. E. Darfur, August 5-13, 1930 (Michelmore).

This species may be separated from its closest ally, atriventris Pic (Rev. zool. bot. afr. 21, 1931, p. 47), by the flavocastaneous head, the black elytra, the flavocinereous pubescence, the unicolored legs, the shorter anal style and the larger size. The short description of atriventris indicates that the posterior tarsi of his type specimen may be missing. Other differences probably exist, but Pic's short description deals chiefly with color - the antennæ and maxillary palpi are not mentioned. 

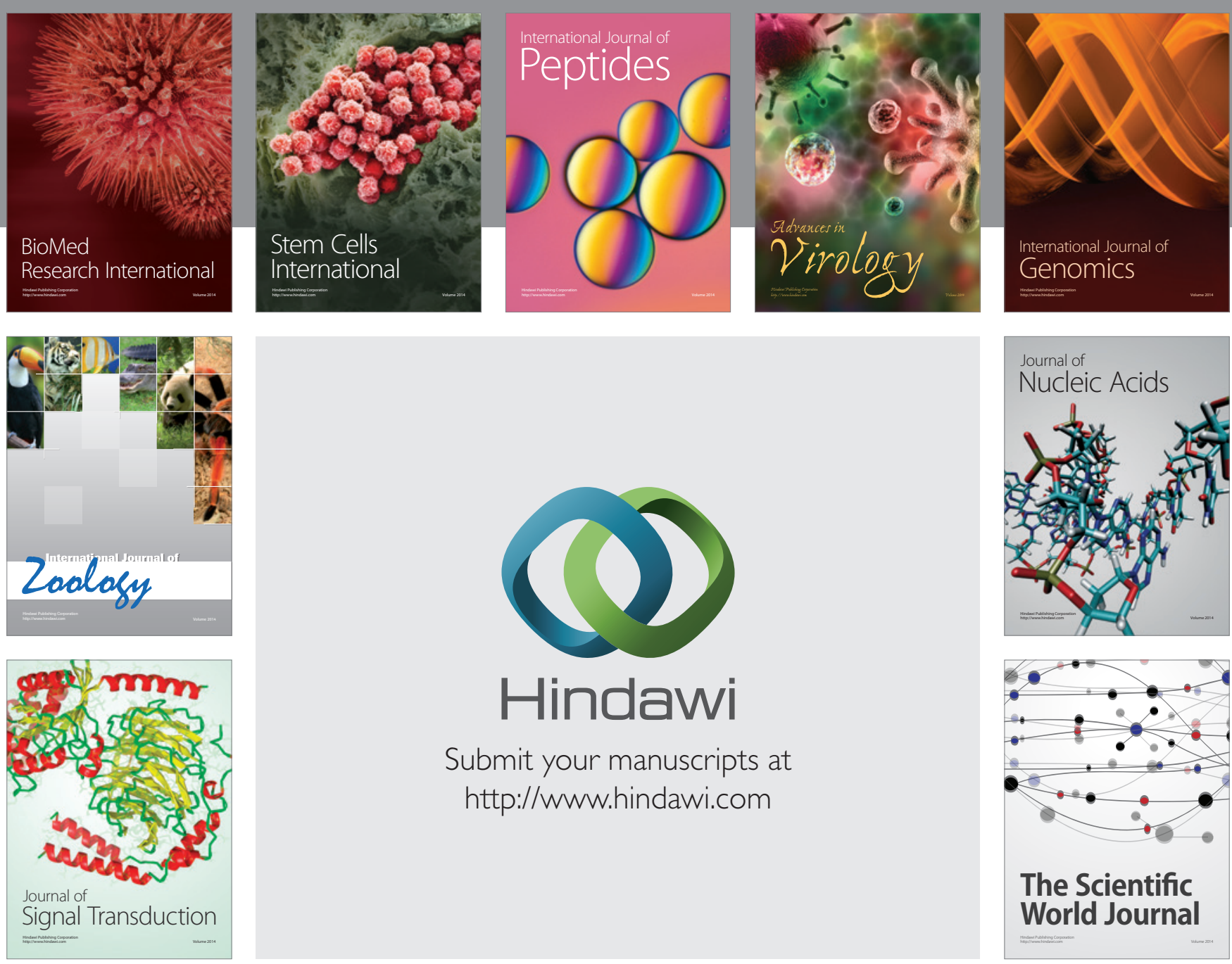

Submit your manuscripts at

http://www.hindawi.com
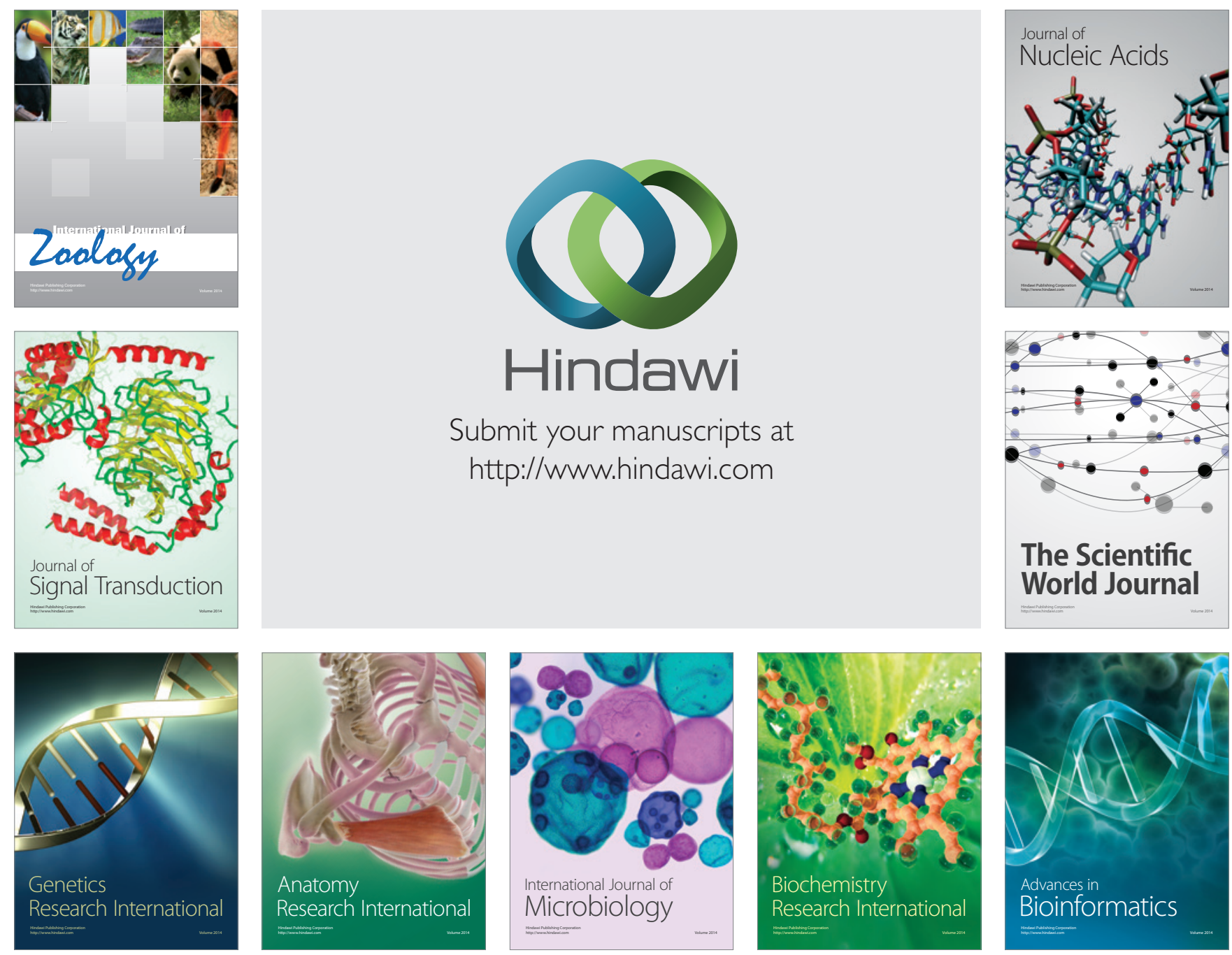

The Scientific World Journal
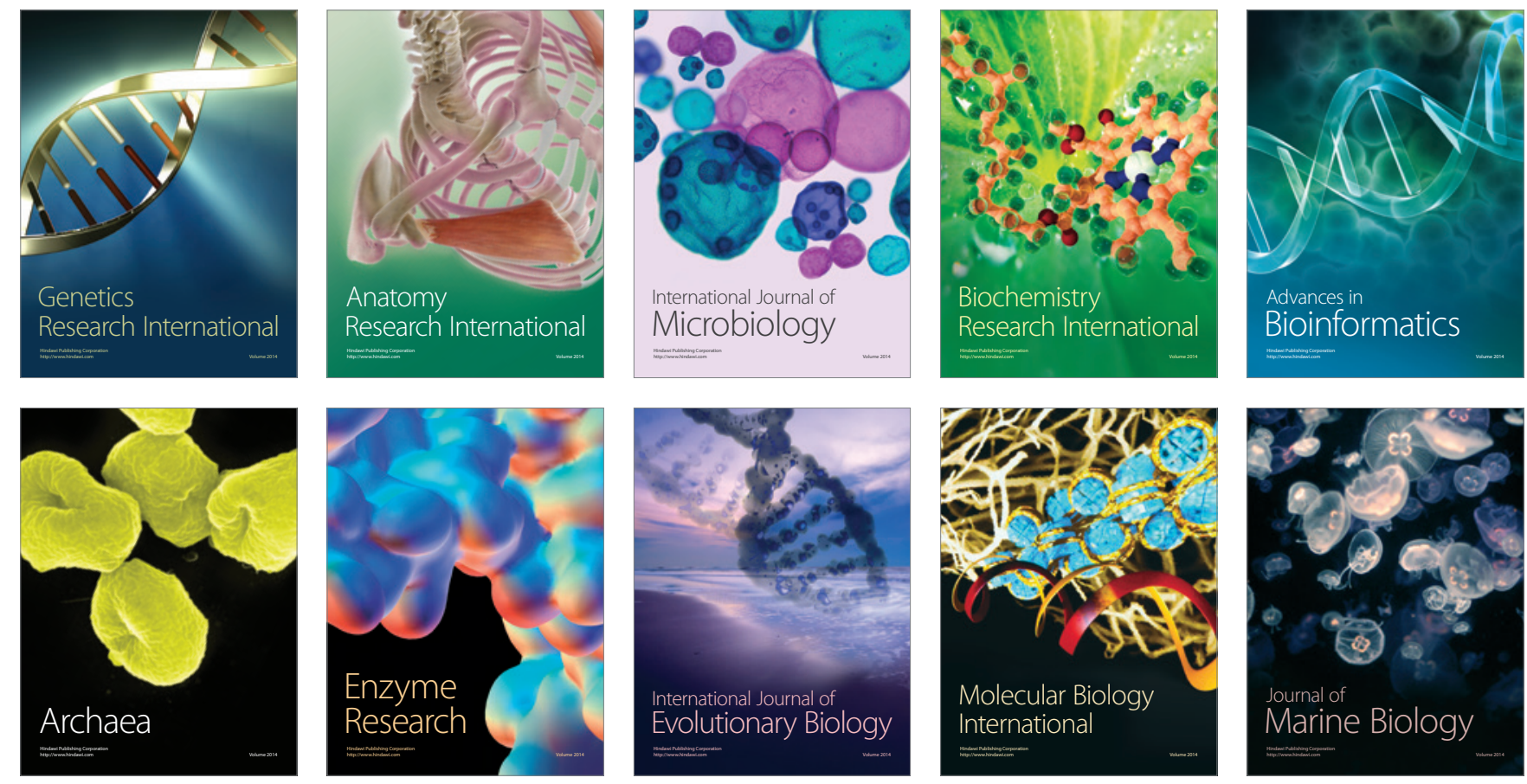